\title{
Titae
}

$32(2017) 445-460$

Ks. Krzysztof Smykowski

Katolicki Uniwersytet Lubelski Jana Pawła II krzysztof.smykowski@kul.pl

\section{CZŁOWIEK I ZWIERZĘTA TOWARZYSZĄCE. REFlEKSJE TEOLOGA MORALISTY}

Man and Pets.

A Moral Theologian's Reflections

„Stajesz się odpowiedzialny na zawsze za to, co oswoiłeś”. A. de Saint-Exupéry, Maty ksiaże

Celem artykułu jest podjęcie teologicznomoczłowiek; teoralnej refleksji nad relacją człowieka wobec zwierząt mu towarzyszących, do których zalicza się psy, koty, niektóre gatunki ptaków, gryzoni i gadów. Badania interdyscyplinarne wskazują na pozytywny wpływ kontaktu ze zwierzętami na psychiczny i emocjonalny rozwój człowieka. Należy podkreślić, że właściciel posiada moralny obowiązek opieki nad zwierzętami, która wyraża się poprzez zapewnienie im odpowiedniego pożywienia i właściwych warunków bytowania oraz utrzymanie dobrego stanu zdrowia. Współcześni ludzie jednak często nie wywiązują się właś- 
ciwie z tych zadań. Nie brakuje przypadków okrucieństwa. Nierzadkie jest jednak także traktowanie zwierząt jak człowieka i otaczanie ich nieproporcjonalną troską, co budzić musi poważne zastrzeżenia moralne.

\section{Abstract}

The aim of this article is to reflect on the relationship of man to his animal companions: dogs, cats, and certain species of birds, rodents and reptiles. Interdisciplinary research points to the positive impact that contact with animals has upon the mental and emotional development of humans. It should be emphasized that owners always have a moral obligation to take care of their animals, which means providing them with adequate food and proper living conditions, as well as maintaining them in good health. Modern people, however, often fail to fulfill this obligation properly. On the one hand, cases of abuse or cruelty towards animals are not infrequent. On the other hand-and the other end of the spectrum-it is not uncommon for some people to treat animals like they were human and surround them with overindulgent, disproportionate care, which must also raise serious moral concern.
KEYWORDS

domestic animals; man; moral theology; pets

Klasycy teologii moralnej, podejmując refleksję na temat zwierząt i relacji człowieka względem nich oraz lokując go w ramach wykładu siódmego przykazania Bożego lub kardynalnej cnoty sprawiedliwości, dokonywali także podziału istot żywych. W świetle tej klasyfikacji wyróżniano zwierzęta domowe (mansueta seu domestica), które ze swej natury są 
związane z człowiekiem. Wykorzystuje on je w różny sposób w swoim gospodarstwie. Do tej grupy zaliczano konie, bydło, owce, drób i psy. Wyróżniano także zwierzęta oswojone (manseufacta seu cicurata). Są one zdolne do samodzielnego życia w naturze. Człowiek jednak pozbawił je wolności i żyją one pod jego władzą. Moraliści w tej grupie wymieniali niektóre gatunki ptaków, króliki, pszczoły oraz ryby bytujące w prywatnych stawach. Ostatni rodzaj stanowią zwierzęta dzikie (fera seu silvestra), które z natury nie podlegają władzy ludzkiej i żyją w naturalnym środowisku. W tej grupie wyróżniano lwy, orły, sępy, jelenie, zające i ryby ${ }^{1}$.

Wydaje się, że na skutek przemian zachodzących w społeczeństwach nowoczesnych, począwszy od XVIII wieku, ten podział nieco stracił na swojej aktualności. Konieczne jest wyodrębnienie jeszcze zwierząt towarzyszących (ang. pets). Zaliczają się do nich zwierzęta z grupy zwierząt domowych lub oswojonych, które nie odgrywają już jednak użytkowej roli w gospodarce człowieka, lecz są towarzyszami jego życia. W tym miejscu należy w pierwszym rzędzie wymienić psy i koty, które nie pełnią już funkcji stróża domostwa czy tępiciela szkodników. Nie brakuje jednak także gryzoni (myszy, szczury, chomiki, świnki morskie, króliki), ptaków (papugi, kanarki), gadów (węże, żółwie) oraz ryb.

Z przeprowadzonych badań statystycznych wynika, że blisko połowa (48\%) Polaków ma przynajmniej jedno zwierzę domowe. Spośród nich zdecydowanie najwięcej (83\%) posiada psa. Dużo mniejszą popularnością cieszy się kot (44\%). Znikomy i oscylujący w granicach błędu statystycznego jest odsetek ptaków (4\%), gryzoni (3\%) i gadów $(1 \%)^{2}$.

Obserwacja świata pokazuje, że hodowla tego rodzaju zwierząt jest zjawiskiem coraz powszechniejszym. Istoty żywe towarzyszą człowiekowi nie tylko w miejscu zamieszkania, lecz także podczas podejmowania różnych aktywności poza

1 Por. Merkelbach, Summna theologiae, 211; Smykowski, „Zwierzęta”, 80.

2 Por. TNS Polska, Zwierzęta, 4-5. 
domem. Są często obecne zarówno w czasie pracy, jak i wypoczynku. To sprawia, że pomiędzy osobą a zwierzęciem powstaje swego rodzaju więź emocjonalna.

Hodowla zwierząt towarzyszących może jednak rodzić pewne problemy o charakterze etycznym. Teologia moralna, będąc żywą refleksją nad urzeczywistnianiem się ideału chrześcijańskiej moralności, nie może pozostać wobec nich obojętna.

\section{1. „TERAPEUTYCZne” ZnACZENIE ZWIERZĄT}

Różne motywy towarzyszą człowiekowi, który rozpoczyna hodowlę zwierząt towarzyszących. Jednym z nich może być dobroczynny wplyw kontaktu $z$ innymi istotami żywymi zarówno na sferę psychiczno-emocjonalną, jak i stan zdrowia fizycznego. Przesłanek dla stwierdzenia tego rodzaju oddziaływania dostarczają badania interdyscyplinarne prowadzone przez lekarzy, psychologów i pedagogów.

W ich świetle osoby posiadające zwierzęta lub przynajmniej mające z nimi regularny kontakt są bardziej spostrzegawcze w relacjach z innymi ludźmi. Nie mają większych problemów z komunikowaniem niewerbalnym i łatwiej integrują się w rozmaitych grupach i wspólnotach ${ }^{3}$. Te ogólne stwierdzenia można odnieść do osób w różnym wieku. Szczególnie doniosły wpływ ma kontakt ze zwierzętami na dzieci oraz osoby w podeszłym wieku.

Dzieci obcujące ze zwierzętami uzyskały wyższe oceny w zakresie ekspresji słownej, wytrwałości, umiejętności koncentracji na wykonywanych zadaniach oraz wrażliwości na potrzeby drugiego człowieka. Z kolei te, które były pozbawione takiej możliwości, zostały określone jako bardziej introwertyczne. Rzadziej szukały kontaktu z rówieśnikami oraz przejawiały mniej pozytywnych zachowań zarówno

3 Por. Wróbel, „Zwierzęta”, 102. 
względem nich, jak i wobec wychowawców oraz nauczycieli. Oznacza to, że regularny kontakt ze zwierzętami w znacznej mierze wpływa (choć całkowicie o nim nie przesądza) na przystosowanie dziecka do rozpoczęcia edukacji przedszkolnej4. Towarzystwo zwierząt może być ponadto stałym źródłem poczucia bezpieczeństwa. Pomaga wreszcie stosunkowo wcześnie unaocznić dziecku fakty związane z życiem i śmiercią, a tym samym choć częściowo przygotować je do przeżycia bolesnych wydarzeńs.

Wykazano także korzystny wpływ towarzystwa zwierząt na osoby w podeszłym wieku. Wyraża się on przede wszystkim w budowaniu pozytywnego nastawienia do siebie i swojego otoczenia poprzez usuwanie barier psychologicznych i społecznych oraz nawiązywanie nowych relacji interpersonalnych. Niemniej istotne jest zachowanie naturalnej harmonii i równowagi psychicznej oraz wsparcie w zaburzeniach koncentracji uwagi ${ }^{6}$.

Stwierdzono ponadto korzystny wpływ na stan zdrowia fizycznego, który został uznany i potwierdzony przez Międzynarodową Organizację Zdrowia (WHO). Już w 1883 roku wykazano oddziaływanie kontaktu ze zwierzętami na obniżenie tętna i ciśnienia krwi, co znacząco zmniejsza ryzyko zachorowania na choroby wieńcowe. Posiadanie zwierzęcia jest wreszcie związane z koniecznością zwiększenia aktywności fizycznej, która z kolei jest niezbędnym warunkiem utrzymania dobrego stanu zdrowia. Naukowo potwierdzona została ponadto zdolność wykrywania niektórych typów nowotworów przez psy. Jej mechanizm opiera się na istnieniu specjalnych komórek zmysłowych pozwalających określać związki chemiczne charakterystyczne dla nowotworu?

Przywołany korzystny wpływ zwierzęcia na człowieka jest wykorzystywany także już wprost w procesie leczenia

\footnotetext{
Por. Połomski, „Zwierzę”, 31; Kulisiewicz, Witaj, piesku, 10.

Por. Kurzeja - Godawa, „Wykorzystanie zooterapii”, 92.

Por. Mamzer, „Stary człowiek”, 72.

Por. Sipowicz - Pietras - Najbert, Dogoterapia, 97-102.
} 
poważnych chorób czy zaburzeń psychicznych. Najczęściej realizowaną jego formą jest dogoterapia (kynoterapia), czyli oddziaływanie przez kontakt z psem. Zdecydowanie rzadziej stosowaną formą terapii jest kontakt $\mathrm{z}$ kotem, czyli felinoterapia. Już samo nazewnictwo wyrażać może dwojakie podejście do tego typu działań. Pierwsze, ograniczając się wyłącznie do spojrzenia medyczno-technologicznego, traktuje zwierzę jako kolejny z leków. Inne zaś wprowadza zwierzę do roli współterapeuty. Wydaje się, że bardziej słuszne jest podejście drugie, i to właśnie ono dominuje we współczesnych opracowaniach i praktyce terapeutycznej.

Kontakt z psem ma szczególne znaczenie w procesie terapii i rehabilitacji dzieci o szczególnych potrzebach edukacyjnych, w tym tych dotkniętych zespołem Downa, autyzmem czy upośledzeniem umysłowym różnego stopnia. Podczas trwania dogoterapii zauważono wyraźny postęp w zakresie szeregu funkcji intelektualnych. Dzieci te, korzystając z pomocy odpowiednio przygotowanego logopedy, wzbogacają swoje słownictwo i wiedzę ogólną. Chętnie uczestniczą w rozmowach, zabawach i grach edukacyjnych, których bohaterem jest pies. Szczególne znaczenie towarzystwa zwierzęcia można zaobserwować w przypadku terapii osób dotkniętych mózgowym porażeniem dziecięcym, którego objawem są niedowłady spastyczne. Kontakt z nim pomaga rozluźniać napięte mięśnie, co znacznie ułatwia rehabilitację?.

Zdecydowanie rzadziej stosowana jest felinoterapia. Zyskuje ona jednak na znaczeniu w Stanach Zjednoczonych i Wielkiej Brytanii. Stwierdzono, że zabiegi pielęgnacyjne, dotyk miękkiej sierści i ciała zwierzęcia, którego temperatura jest o dwa stopnie wyższa od temperatury ciała ludzkiego, łagodzi bóle reumatyczne oraz mobilizuje do ruchu w stawach dotkniętych różnego rodzaju ograniczeniami. Zaletą

8 Por. Petrantoni, „Il coinvolgimento”, 131-132; Pawlik-Popielarska, Terapia, 23-24.

9 Por. Popielarska, „Pies”, 82. 
tej formy terapii jest także to, że kot nie potrzebuje specjalnej tresury ${ }^{10}$.

Przytoczone powyżej korzyści związane z posiadaniem zwierząt lub uczestnictwem $w$ różnych formach terapii $z$ ich udziałem stanowią konkretne zobowiązanie moralne przynajmniej do rozważenia zakupu zwierzęcia lub umożliwienia częstszego przebywania w jego towarzystwie osobom dotkniętym chorobami lub zaburzeniami, przy leczeniu których zastosowanie może mieć dogoterapia lub felinoterapia. Przy tych rozważaniach trzeba wziąć pod uwagę także inne czynniki. Zaliczają się do nich m.in. ewentualne uczulenia na sierść, warunki lokalowe czy możliwość zapewnienia odpowiednich warunków bytowych zwierzętom.

\section{KonieCZność ZAPEWNIENIA ODPOWIEDNIEGO POZIOMU DOBROSTANU}

Zwierzęta są w stanie odczuwać ból i stres, których człowiekowi nie wolno wprost zadawać żadnej innej istocie ${ }^{11}$. Ich minimalizacja wiąże się nierozerwalnie z tworzeniem właściwych warunków bytowania i rozwoju. W tym kontekście należy podkreślić dobitnie, że szczególne zobowiązania człowiek posiada wobec istot żywych hodowanych przez niego w swoim domu. $Z$ tego względu są one pozbawione możliwości samodzielnego zaspokajania swoich potrzeb. Niektóre zaś gatunki na skutek udomowienia całkowicie utraciły taką zdolność. Moralnym obowiązkiem osoby ludzkiej będzie zatem zapewnienie zwierzętom odpowiedniego poziomu dobrostanu.

W publikacjach naukowych jest on definiowany najczęściej jako zdolność zwierzęcia do radzenia sobie ze środowiskiem i jego wpływami ${ }^{12}$. Definicja ta posiada szereg implikacji. Jest

10 Por. Kurzeja - Godawa, „Wykorzystanie zooterapii”, 90-91.

11 Por. Wróbel, „Zwierzęta”, 102.

12 Por. Empel, „Dobrostan”, 65. 
on stanem zmiennym i jako taki jest uzależniony od czynników zewnętrznych, na które z kolei w znacznej mierze wpływ może mieć działanie człowieka. Jego poziom może być zaś mierzony przy pomocy metod naukowych, niezależnych od przekonań moralnych ${ }^{13}$.

Formą oceniania dobrostanu zwierząt jest odniesienie do ich kondycji kategorii Pięciu Wolności (Five Freedoms). Jest to pewien stan idealny, do którego winny zmierzać warunki hodowli zwierząt. Zostały one sformułowane w Raporcie Brambella w 1965 roku i odniesione przede wszystkim do zwierząt gospodarskich. Można je jednak z powodzeniem zastosować także do zwierząt towarzyszących. Obejmują one wolność od głodu i pragnienia, wolność od dyskomfortu, wolność od bólu, zranienia i chorób, wolność do normalnego zachowania oraz wolność od stresu i strachu ${ }^{14}$.

Przekładając te postulaty na poziom hodowli zwierząt domowych, należy stwierdzić, że zwierzęciu trzeba zapewnić przede wszystkim stały dostęp do świeżej wody oraz zbilansowanej karmy, która odpowiadałaby jego zapotrzebowaniu energetycznemu. Niemniej istotne jest zorganizowanie właściwej przestrzeni życiowej proporcjonalnej do rozmiarów zwierzęcia. Winno ono w niej posiadać odpowiednie miejsce dla odpoczynku. Właściciel posiada ponadto obowiązek regularnej kontroli stanu zdrowia i poddawania swego pupila zabiegom profilaktycznym (okresowe szczepienia i odrobaczanie), a w razie potrzeby także otoczenia opieką lekarsko-weterynaryjną. Istotne dla prawidłowego rozwoju niektórych gatunków zwierząt domowych jest ponadto przynajmniej sporadyczne zapewnienie możliwości kontaktu z innymi zwierzętami. Ten postulat w sposób szczególny odnosi się do psów.

Szczególne obowiązki człowiek posiada wobec zwierząt chorych i starych. Taka postawa jest głęboko wpisana w ludzką naturę. Jako przykład można przywołać niektóre ludy zamiesz-

14 Por. El-Jai, „Rola bioetyki”, 231. 
kujące wyspy Archipelagu Malajskiego. Wykorzystują one makaki świńsko-ogonowe (lampudery) do zbioru orzechów kokosowych. Gdy na skutek wieku nie są one w stanie wypełniać tych zadań, traktuje się je jako zwierzęta pokojowe, otaczając opieką i pozwalając dożyć swoich $\mathrm{dni}^{15}$. O takiej postawie jednak współczesny człowiek zdaje się niekiedy zapominać.

Mogą zdarzyć się jednak sytuacje, gdy stan zdrowia zwierzęcia jest bardzo ciężki, towarzyszy mu bardzo silny ból, a zastosowane działania nie niosą istotnej nadziei na wyleczenie. Niejednokrotnie terapia poważnych schorzeń może przerastać możliwości finansowe przeciętnego człowieka (leki weterynaryjne są kilkukrotnie droższe od odpowiadającym im leków stosowanych w terapii podobnych chorób u człowieka). W takiej sytuacji posiada on prawo uśmiercenia zwierzęcia. Taka procedura w medycynie weterynaryjnej nosi nazwę eutanazji ${ }^{16}$. Wydaje się, że w pewnych sytuacjach może ono stanowić wręcz trudny obowiązek moralny i wynikać $\mathrm{z}$ dobrze pojętego współczucia wobec chorego zwierzęcia ${ }^{17}$. Ważne jest jednak to, aby zostało ono dokonane przez odpowiednio przeszkolone osoby przy użyciu właściwych metod, które nie potęgowałyby bólu odczuwanego przez zwierzę.

\section{NiektóRe SytUACJE NiePraWidŁOWE}

Nie zawsze człowiek potrafi w sposób właściwy wypełniać opisane zobowiązania. Źródłem tych zaniedbań są dwa skrajne poglądy, który nie można pogodzić z chrześcijańską

15 Vetulani, „Być ludzkim”, 52.

16 Wydaje się, że zastosowanie tego terminu do uśmiercania zwierząt jest niewłaściwe. W sensie ścisłym należy ją bowiem rozumieć jako „czyn lub zaniedbanie, które ze swej natury lub w intencji działającego powoduje śmierć w celu usunięcia wszelkiego cierpienia" (EV, nr 65). W przypadku zwierzęcia trudno mówić o cierpieniu. Nie może ono także działać z intencją jego wyeliminowania.

17 Wolniewicz, „Eutanazja”, 73. 
wizją relacji człowieka wobec zwierząt. Są to reifikacja istot żywych oraz zoopersonalizm.

Reifikcja zwierząt jest w znacznej mierze konsekwencją stosowania prawa rzymskiego, które stało się jednym z filarów cywilizacji europejskiej. Umieszczało ono zwierzęta w kategorii rzeczy i takie przepisy do nich odnosiło. We współczesnych systemach prawnych daje się zauważyć odchodzenie od takiego spojrzenia. Ustawodawstwo wielu państw podkreśla, że zwierzę nie jest rzeczą, a przepisy dotyczące rzeczy odnosi jedynie do form nabywania prawa własności zwierzą ${ }^{18}$.

Konsekwencją reifikacji jest niewłaściwe traktowanie zwierząt. Człowiek nie tylko nie wypełnia swoich obowiązków względem nich, które zostały nakreślone powyżej. Zdarza się, że wprost zadaje im ból i naraża na stres bez istnienia proporcjonalnych przyczyn dla podjęcia takiego działania. Ofiarami takich działań są przede wszystkim zwierzęta domowe. Sprzeczne z ludzką godnością są jakiekolwiek przejawy okrucieństwa względem innych istot żywych. Jego powołaniem jest zaś przeciwdziałaniem jakimkolwiek formom cierpienia ${ }^{19}$. Na niegodziwość takiego postępowania wskazywali już klasycy teologii moralnej. W obawie o potencjalne zrównanie statusu ludzi i zwierząt nie formułowali oni co prawda obowiązków człowieka wobec zwierząt, ani tym bardziej ich praw. Dręczenie zwierząt nazywali jednakże czynem sprzecznym z rozumem, uznając go za poważny występek przeciwko cnocie umiarkowania, a zwłaszcza cnocie łagodności ${ }^{20}$. Takie niegodziwe zachowania stają się bardzo często przygotowaniem gruntu pod analogiczne postawy wobec drugiego człowieka ${ }^{21}$.

Szczególną formą znęcania się nad zwierzętami jest ich porzucanie. Zwierzę przywiązane emocjonalnie do człowieka jest najczęściej niezdolne do samodzielnego życia poza

18 Por. Radecki, Ustawy, 45.

19 Por. LS, nr 130; Hendricks, „O właściwą postawę”, 54.

20 Por. Noldin, Summa, 317; Wróbel, „Zwierzęta”, 86.

21 Por. LS, nr 92; Wróbel, „Zwierzęta”, 102-103. 
domem, w tym do zdobywania pokarmu. Jeśli nie zostanie uratowane przez innych ludzi, może paść w krótkim czasie ofiarą dzikiego zwierzęcia. Z zadowoleniem należy przyjąć ostatnie zmiany w prawie polskim, które zakwalifikowały porzucanie zwierząt, w tym szczególnie psów i kotów, za formę znęcania ${ }^{22}$. Trzeba jasno stwierdzić, że wobec zwierząt domowych człowiek posiada obowiązek opieki do końca ich życia. Zwolnienie z niego może nastąpić jedynie z bardzo poważnych powodów. Zaliczyć do nich można chociażby pojawienie się alergii odzwierzęcych czy też niemożliwość zapewnienia należytych warunków bytowania. Nie należy do nich chęć wyjazdu na urlop, w którym przeszkodą jest pies czy $\operatorname{kot}^{23}$. Z tego więc powodu każdy zakup zwierzęcia winien być poprzedzony zastanowieniem się, czy człowiek posiada możliwości, a przede wszystkim wolę podjęcia nowych obowiązków.

Mimo wzrostu świadomości społecznej ilość ujawnionych przestępstw znęcania się nad zwierzętami od lat utrzymuje się na wysokim poziomie (ok. 1,5 tysiąca rocznie). Niepokojem musi jednak napawać fakt, że systematycznie spada wskaźnik wykrycia ich sprawców ${ }^{24}$. Jest to niewątpliwie poważne wyzwanie stojące przed organami ścigania (policją i prokuraturą).

Ze wzrostem ilości zwierząt domowych związany jest jeszcze jeden problem. W ostatnich latach na terenie Polski powstają liczne hodowle, których właściciele kierują się wyłącznie pragnieniem zysku. Nie zapewniają zwierzętom odpowiednich warunków bytowania. Nie uwzględniają oni szczególnych potrzeb zwierząt ciężarnych i nie liczą się z naturalnymi uwarunkowaniami związanymi z przekazywaniem $\dot{z ̇ y c i a}^{25}$. Świadomy zakup zwierzęcia z takiej pseudohodowli

22 Por. Radecki, Ustawy, 67-69.

23 Por. Empel, „O nierównym traktowaniu”, 889.

24 Por. http://www.statystyka.policja.pl/st/wybrane-statystyki/znee canie-sie-nad-zwier/50889,Znecanie-sie-nad-zwierzetami.html [18.11.2016]

25 Por. Linzey, „Gli animali”, 127. 
należy rozpatrywać $\mathrm{w}$ kategorii współpracy w złym postępowaniu drugiego człowieka.

$\mathrm{Na}$ przeciwległym biegunie należy zlokalizować zoopersonalizm. Jest to prąd filozoficzny i społeczny, który dąży do zrównania lub przynajmniej maksymalnego zbliżenia statusu człowieka i zwierząt. Rodzi on konkretne konsekwencje w relacjach pomiędzy osobą ludzką a innymi bytami ożywionymi. Wprawdzie Katechizm Kościoła Katolickiego stwierdza, że „można kochać zwierzęta”, dodaje jednak zaraz, że „nie powinny one jednak być przedmiotem uczuć należnych jedynie osobom" 26 .

Takie tendencje daje się jednak zauważyć we współczesnym społeczeństwie. Psy i koty w nowoczesnej rodzinie traktowane są jako jej pełnowartościowi członkowie. Posiadają one status zbliżony do dzieci, występując w swoich dziecięcych rolach do końca swego życia ${ }^{27}$. Takie postawy daje się zaobserwować szczególnie w rodzinach dotkniętych ideologią DINKs (double income, no kids). Jej reprezentantami są przede wszystkim dobrze sytuowani przedstawiciele biznesu i wolnych zawodów, przez których dziecko jest postrzegane jedynie w kategoriach przeszkody w realizacji kariery. Swoje naturalne potrzeby próbują zaspokajać przez udział w akcjach charytatywnych ${ }^{28}$ lub poprzez przelewanie swoich uczuć na zwierzęta domowe. Podobną rolę zwierzęta odgrywają niekiedy w domach osób w podeszłym wieku, dla których niejednokrotnie są jedynymi towarzyszami życia ${ }^{29}$. Źródeł takiego stanu rzeczy należy dopatrywać najczęściej w nieumiejętnym przeżywaniu samotności, trudnych przeżyciach bądź krzywdach doznanych ze strony innych ludzi.

Takiej postawie towarzyszy bardzo często ponoszenie nieproporcjonalnych wydatków na utrzymanie tych zwierząt. Nie wiążą się one wprost z zaspokajaniem ich koniecznych

\footnotetext{
26 KKK, nr 2418.

27 Por. Kośmicki, „Ukochane zwierzęta”, 22.

28 Por. Pokrywka, Antropologiczne podstawy, 77.

29 Por. Kośmicki, „Ukochane zwierzęta”, 22.
} 
potrzeb. Takie postępowanie jest przejawem poważnej niesprawiedliwości przede wszystkim względem innych ludzi, w tym niekiedy wobec członków najbliższej rodziny, którym pieniądze te mogłyby pomóc wyjść z trudnej sytuacji egzystencjalnej ${ }^{30}$.

Przejawem tendencji zoopersonalistycznych jest zakładanie cmentarzy dla zwierząt. Ich początek w krajach Europy Zachodniej i Ameryki Północnej przypada na schyłek XIX wieku. W Polsce takie miejsca pochówku zaczęły powstawać w latach dziewięćdziesiątych XX wieku. Wprawdzie trzeba uznać konieczność ich istnienia, co zapobiegać ma grzebaniu zwierząt w miejscach do tego nieprzeznaczonych i powstawaniu zagrożenia sanitarno-epidemiologicznego. Zastrzeżenia o charakterze moralnym budzić może jednak przepych ustawianych tam tablic czy nagrobków oraz sprawowany tam swego rodzaju kult zmarłych towarzyszy życia ${ }^{31}$.

\section{Podsumowanie}

Współcześni ludzie, których zdecydowana większość żyje w miastach, mają ograniczone możliwości kontaktu z naturą. Jego namiastką jest towarzystwo zwierząt domowych. Badania prowadzone w ostatnich latach wskazują, że ten kontakt może mieć dobroczynny wpływ. Stymuluje on prawidłowy rozwój człowieka. Może być także formą terapii licznych chorób psychicznych i somatycznych.

Niestety, podejście do zwierząt domowych jest często pochodną dwóch skrajnych postaw, które obce są katolickiej refleksji teologicznomoralnej. Nie brakuje przypadków znęcania się nad istotami żywymi. $\mathrm{Z}$ drugiej jednak strony relatywnie często zdarzają się próby antropomorfizacji zwie-

30 „Niegodziwe jest wydawanie na nie [zwierzęta] pieniędzy, które mogłyby w pierwszej kolejności ulżyć ludzkiej biedzie" (KKK, nr 2418).

31 Por. http://www.cmentarz-zwierzat.pl [18.11.2016]. 
rząt. Istnienie takich tendencji stanowić winno inspirację $\mathrm{dla}$ pastoralnej działalności Kościoła. Należy bowiem kształtować postawy wiernych w duchu życzliwości i wrażliwości na wartości właściwe naturze i egzystencji zwierzą ${ }^{32}$, w tym przede wszystkim zwierząt domowych, które pozostają najbliższe człowiekowi.

\section{BIBLIOGRAFIA}

El-Jai J., „,Dobrostan zwierząt w naukach humanistycznych i przyrodniczych", Studia Ecologiae et Bioethicae 13/2 (2008) 183-190.

El-Jai J., „Rola bioetyki w kształtowaniu humanitarnego podejścia do zwierząt", Zeszyty Filozoficzne 14-15 (2009) 225-234. Empel W., „Dobrostan zwierząt”, Życie Weterynaryjne 71/3 (1996) 65-67.

Empel W., „O nierównym traktowaniu zwierząt”, Życie Weterynaryjne 84/11 (2008) 889-891.

Franciszek, Encyklika Laudato si' (2015) (=LS).

Hendricks M., „O właściwą postawę wobec zwierząt”, L'Osservatore Romano (wydanie polskie) 22/10 (2001) 53-55.

Jan Paweł II, Encyklika Evangelium vitae (1995) (=EV).

Katechizm Kościoła Katolickiego (Poznań: Pallottinum ${ }^{2} 2002$ ) (=KKK).

Kośmicki E., „Ukochane zwierzęta. Emocjonalne więzi pomiędzy człowiekiem a zwierzętami”, Wszechświat 98/3 (1997) 21-23.

Kulisiewicz B., Witaj, piesku! Dogoterapia we wspomaganiu rozwoju dzieci o specjalnych potrzebach edukacyjnych (Kraków: Impuls 22011).

Kurzeja A. - Godawa J., „Wykorzystanie zooterapii w terapii pedagogicznej na przykładzie terapii z udziałem psa", Chowanna 32 (2009) 85-96.

Linzey A, „Gli animali da compagna (pet)”, Fondamenti di bioetica animale (red. G. Russo) (Torino: Elledici 2007) 123-130.

32 Por. Wróbel, „Zwierzęta”, 102. 
Mamzer H., „Stary człowiek i pies”, Horyzonty Wychowania 14/32 (2015) 63-83.

Merkelbach B.H., Summna theologiae moralis ad mentem D. Thomae et ad normam iuris novi. II. De virtutibus moralibus (Brugis: Desclée de Brouwer ${ }^{10} 1959$ ).

Noldin H., Summa theologiae moralis. II. De praeceptis (Innsbruck: Verlag Felizian Rauch ${ }^{30} 1954$ ).

Pawlik-Popielarska B., Terapia zudziatem psa (Gdańsk: Wydawnictwo Medyczne „Via Medica” 2005).

Petrantoni G., „Il coinvolgimento degli animali da compagna nella cura dell'uomo (pet therapy)", Fondamenti di bioetica animale (red. G. Russo) (Torino: Elledici 2007) 131-137.

Pokrywka M., Antropologiczne podstawy moralności matżeństwa i rodziny (Lublin: Wydawnictwo KUL 2010).

Połomski P., ,Zwierzę w domu a przystosowanie dziecka do przedszkola", Matżeństwo i Rodzina 2/4 (2002) 29-31.

Popielarska B., „Pies «terapeutyczny» - wspieranie procesu terapeutycznego dzieci o zaburzonym rozwoju za pomocą dogoterapii", Psychologia rozwojowa 7/1 (2002) 81-86.

Radecki W., Ustawy o ochronie zwierzat. Komentarz (Warszawa: Difin 2015).

Sipowicz K. - Pietras T. - Najbert E., Dogoterapia (Warszawa: Wydawnictwo Naukowe PWN 2016).

Smykowski K., „Zwierzęta jako przedmiot przedsoborowej myśli teologicznomoralnej", Studia Bydgoskie 8 (2014) 77-88.

TNS Polska, Zwierzęta w polskich domach (Warszawa: TNS Polska 2014).

Vetulani J., „Być ludzkim wobec zwierząt laboratoryjnych”, Wszechświat 91/5 (1990) 49-52.

Wolniewicz B., „Eutanazja w świetle filozofii”, Edukacja Filozoficzna 23 (1997) 71-84.

Wróbel J., „Zwierzęta i ich prawa”, Prawa cztowieka. W 60. Rocznice Powszechnej Deklaracji Praw Cztowieka. Przestanie moralne Kościota (red. K. Jeżyna - T. Zadykowicz) (Lublin: Wydawnictwo KUL 2010) 79-103. 
Ks. Krzysztof SMYKowski, prezbiter diecezji bydgoskiej, doktor nauk teologicznych w zakresie teologii moralnej, asystent w Katedrze Bioetyki Teologicznej w Instytucie Teologii Moralnej KUL, członek Stowarzyszenia Teologów Moralistów, Europejskiego Stowarzyszenia Teologów Katolickich i Stowarzyszenia „Bioethicists in Central Europe" (BCE), członek Lokalnej Komisji Etycznej do Spraw Doświadczeń na Zwierzętach w Lublinie. 